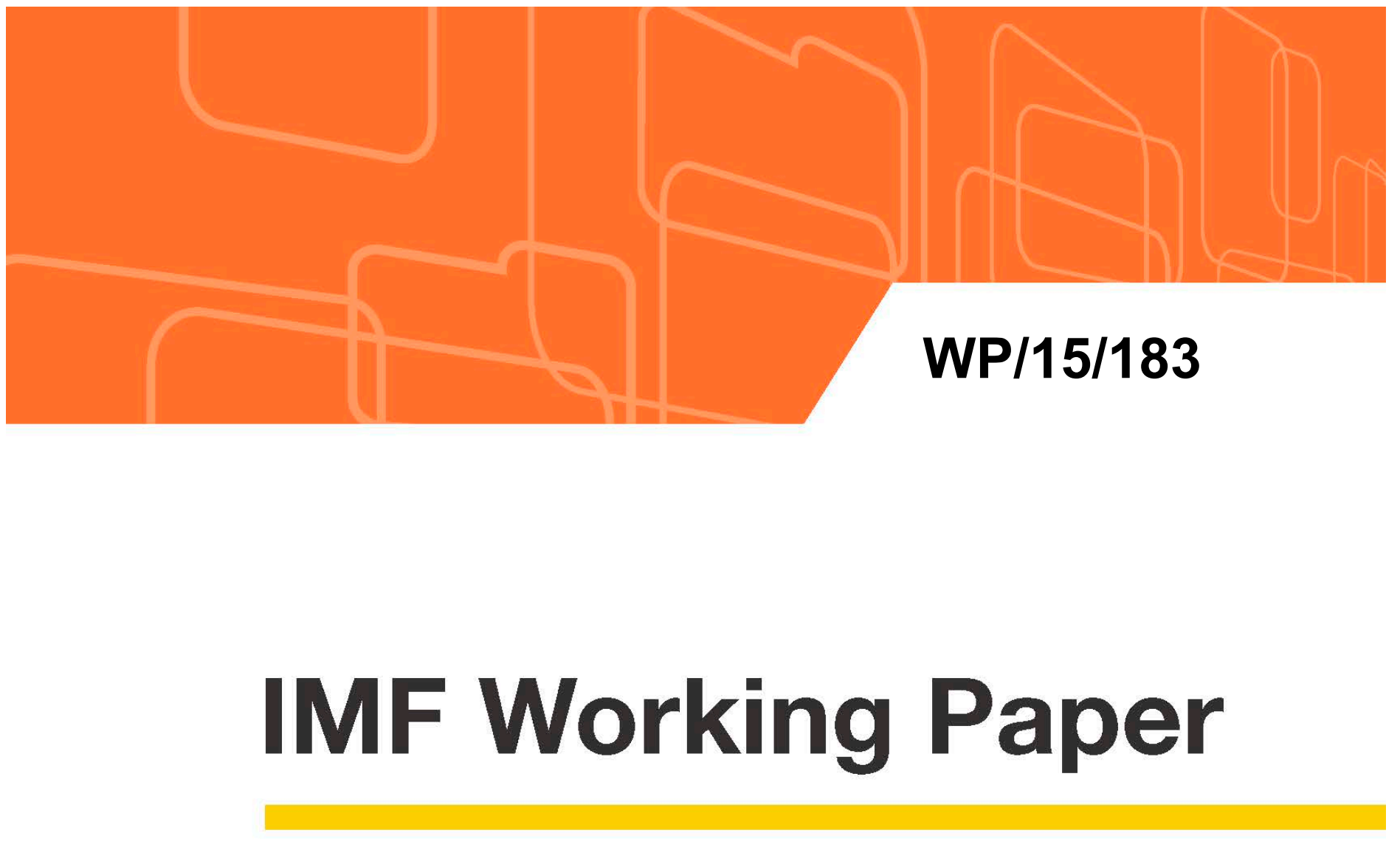

\title{
Production Offshoring and Investment by Japanese Firms
}

by Joong Shik Kang and Shi Piao

IMF Working Papers describe research in progress by the author(s) and are published to elicit comments and to encourage debate. The views expressed in IMF Working Papers are those of the author(s) and do not necessarily represent the views of the IMF, its Executive Board, or IMF management.
I
$N$ T E R
N A T I O N A L
M O N E T A R Y
$F \cup N \quad D$ 


\title{
IMF Working Paper
}

Asia and Pacific Department

\section{Production Offshoring and Investment by Japanese Firms \\ Prepared by Joong Shik Kang and Shi Piao ${ }^{1}$}

Authorized for distribution by Luc Everaert

July 2015

\section{IMF Working Papers describe research in progress by the author(s) and are published to elicit comments and to encourage debate. The views expressed in IMF Working Papers are those of the author(s) and do not necessarily represent the views of the IMF, its Executive Board, or IMF management.}

\begin{abstract}
We trace Japanese corporate investment across different types of firms over the past decades and estimate the main determinants of investment. We find that there are differences in investment behavior between firms expanding abroad and those operating mainly in domestic markets. On the back of a trend increase in production offshoring, investment by large companies, especially those in the transportation sector, is more positively associated with cash flow while responding less to $\mathrm{Q}$ ratio. These findings are consistent with the subdued recovery of private investment in recent years despite booming stock markets and the large build up of cash holdings by Japanese corporates.
\end{abstract}

JEL Classification Numbers: E22; E61

Keywords: Japan; Investment; Capital; Offshoring; Economic growth Author’s E-Mail Address: jkang@imf.org; spiao@imf.org

\footnotetext{
${ }^{1}$ We would like to thank Luc Everaert and Stephan Danninger for valuable comments.
} 


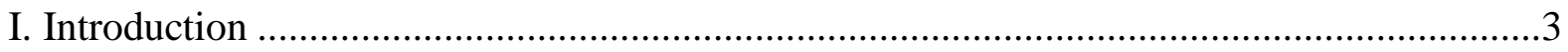

II. Investment Trend by Different Types of Firms …...................................................

III. Panel Regression with Firm-Level Data ................................................................

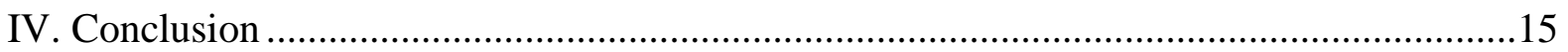

Figures

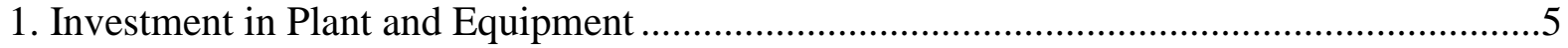

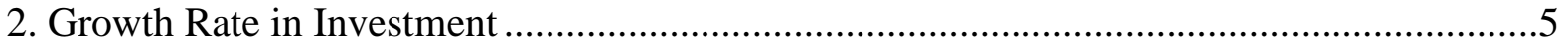

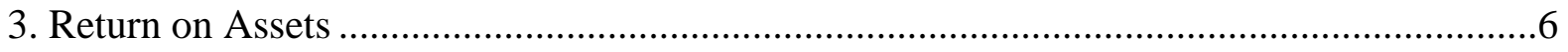

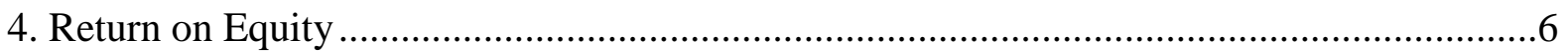

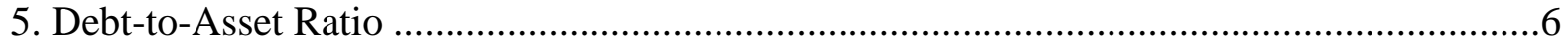

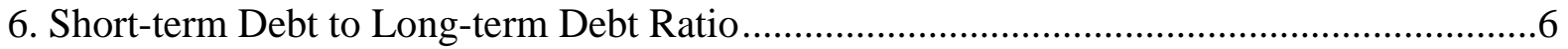

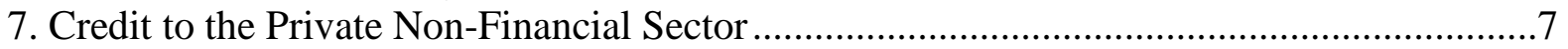

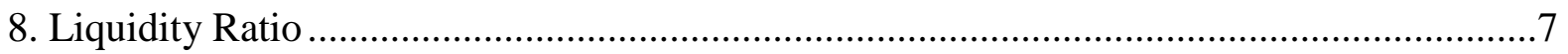

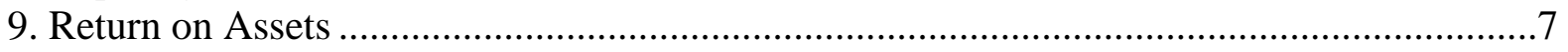

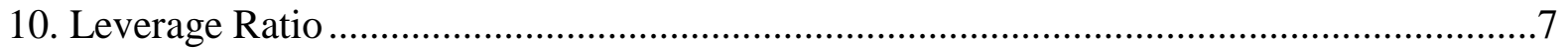

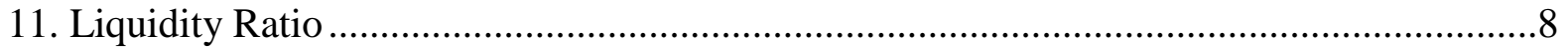

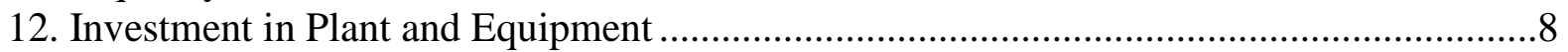

13. Investment by Manufacturing Sector .......................................................................

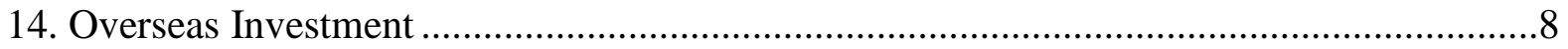

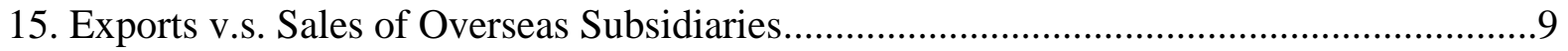

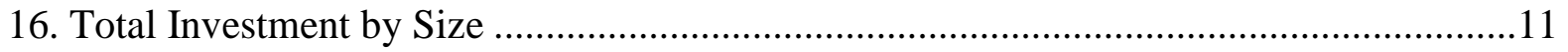

17. Total Investment by Overseas Operations ...............................................................11

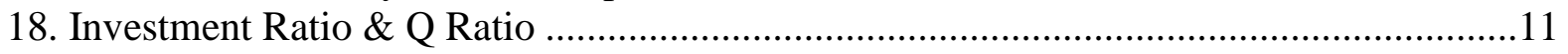

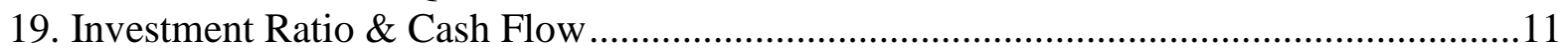

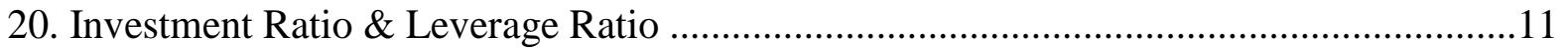

21. Investment Ratio \& Lagged Investment Ratio..............................................................11

Appendix

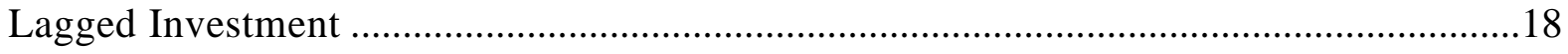

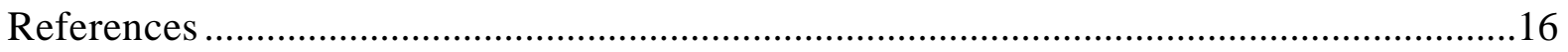




\section{INTRODUCTION}

To increase potential growth over the medium term in Japan, capital accumulation and productivity gains need to become the main drivers of growth. Headwinds from Japans' shrinking labor force will continue as population is shrinking at about 0.3 percent a year. With a public debt-to-GDP ratio of about 250 percent, the fiscal stance needs to remain restrictive over the medium to long term, although the pace of consolidation should be measured to strike a balance between reducing fiscal risks and maintaining growth and inflation momentum.

So far, the recovery of private investment has remained sluggish despite very favorable financial conditions after the launch of Abenomics. Since the Bank of Japan embarked on quantitative and qualitative easing in April 2013, Japanese government bond yields declined further and both bank lending rates and corporate bond yields fell to historic lows. The profitability of Japanese firms has improved significantly partly thanks to the sharp yen depreciation. However, private investment has not picked up as anticipated. Kang (2014) finds that firms' expectations of demand growth over the medium term is a key determinant for corporate investment, implying that still weak private investment is partly due to slow progress in structural reforms, which has not yet substantially boosted confidence and improved the demand outlook.

To better understand the sluggish recovery of private investment, we complement this approach by tracing investment behavior across different types of firms over the past decades and econometrically estimating the main determinants of their investment decisions. In particular, we pay attention to the potentially different investment behavior of large companies on the back of a trend increase in overseas expansion. More specifically, we seek to answer the following questions:

- Have there been differences in investment behavior across different types of firms over the past economic cycles?

- What are main determinants for investment across different types of firms?

- What has been the impact of a trend increase in production offshoring by Japanese firms on their investment decisions?

To answer these questions, we first trace investment behavior and financial conditions across different types of firms based on corporate survey data. Then, we move to firm-level data on listed companies to estimate the standard neoclassical investment model, which relates investment to expectations of future profitability, cash flow, leverage as well as lagged investment. Main findings are as follows: 
- Recovery of private investment after the recent global financial crisis has been slow in both manufacturing and non-manufacturing sectors despite improvement in profitability and liquidity conditions.

- $\quad$ Expectations of future profitability, cash flow, and leverage are all important factors for overall investment behavior of Japanese firms.

- $\quad$ For large firms, in particular those who have expanded abroad for production offshoring, cash flow has been the most important factor behind their investment although they are less liquidity constrained than the others.

- $\quad$ These findings are consistent with recent sluggish recovery of domestic corporate investment despite notable improvement in profitability and large build up of cash holdings.

The remainder of the paper is structured as follows. Section II discusses stylized facts about investment behavior across different types of firms based on corporate survey data. In Section III, we estimate the standard investment model for different types of firms to better understand their different behavior using firm-level data. We conclude in Section IV with short discussion on policy implication.

\section{INVESTMENT TREND BY DIFFERENT TYPES OF FIRMS}

We first discuss developments in investment as well as financial conditions for different types of firms over the past economic cycles. ${ }^{2}$ The corporate financial statement (so-called corporate survey) provides long time series data for firms' balance sheets and income statements as well as information on investment for more than fifty years. It surveys more than 2.7 million firms and total investment in this survey accounts for about two-thirds of aggregate private non-residential investment in the national accounts. As it provides information not only in aggregate form but also broken down across some different types of firms, it helps us understand different developments across different types of firms which are masked in aggregate data.

Investment in the manufacturing sector has been more sensitive to economic cycles over the last three decades than that of non-manufacturing firms (Figures 1 and 2). After the bubble burst in the early 1990s, manufacturing firms cut their investment substantially. The annual average decline of investment for the period of 1990 to 2002 was about 4 percent a year, twice as large as that of non-manufacturing firms. Reflecting this difference, the share of manufacturing sector in total investment declined to about 30 percent in the early 2000s from the peak of 45 percent in early 1980s. In contrast, during the global economic boom period in the mid-2000s, investment by manufacturing firms surged by more than 10 percent a year,

\footnotetext{
${ }^{2}$ See Kang (2015a) for more comprehensive discussion of Japanese corporate investment.
} 
twice as much as that of non-manufacturing firms. Accordingly the manufacturing sector's share in total investment recovered to about 40 percent. With the onset of the global financial crisis, both sectors cut their investment significantly by more than 10 percent per year. As noted by Lee and Syed (2010), there was a more synchronized drop in exports and investment during this period, consistent with a larger decline of investment in the manufacturing sector.

However, the investment recovery after the crisis has been slow in both manufacturing and non-manufacturing sectors. Although more than two years have passed since the government embarked on aggressive policies to exit from decades-long deflation and low growth, the pace of real GDP growth has remained similar to the post-bubble period at about 1 percent per annum. Corporate investment is not an exception and has been broadly flat in both manufacturing and non-manufacturing sectors. Exports began to recover on the back of the sharp yen depreciation since the launch of Abenomics, but it has not been fed through to investment yet. The Tankan survey shows that there still remains excess capacity in the manufacturing sector, implying that it will take some time for an export recovery to feed through to investment.
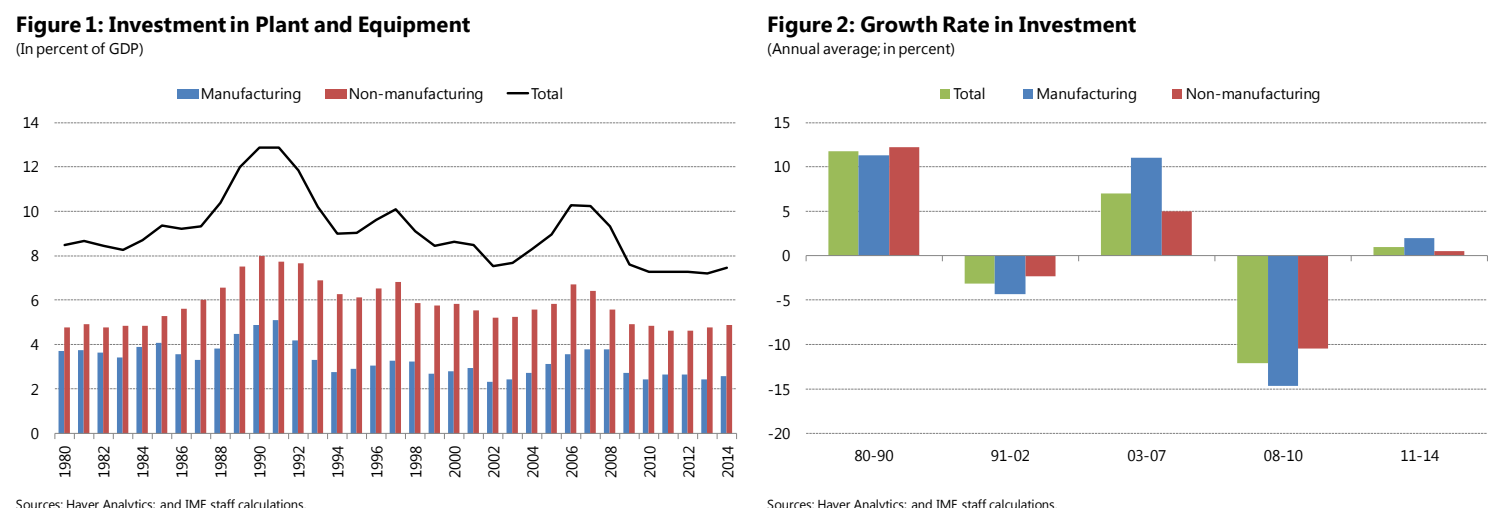

Considering the close comovement between corporate investment and profitability during previous cycles, the recent slow recovery of corporate investment is exceptional. In line with standard theory and empirical findings that firms' profitability is an important driver of corporate investment, we can observe that profitability was high during the booms in 1980s and mid-2000s when investment picked up strongly. Return on asset (ROA) of overall industry was about 1.5 during these periods, more than twice as much as during other periods (Figure 3). Return on equity (ROE) also was much higher during these periods at above 5 (Figure 4). As in the case of investment, we can also observe that profitability of manufacturing firms show more cyclicality over the past cycles. After the recent global financial crisis, Japanese firms' profitability rose significantly and both ROA and ROE over the last 3-4 years are comparable to those during the previous booming period in mid-2000s. Nonetheless, corporate investment still remains subdued. 
Japanese firms have deleveraged significantly over the past two decades and current leverage is comparable to that in other advanced economies. As noted in Kang (2014), Japanese firms have paid back significant amounts of debt over the last 25 years, amounting to about 40 percentage points of GDP. So the leverage ratio, measured as total debt to asset ratio, has declined by more than 10 percent in both manufacturing and non-manufacturing sectors over this period and firms also depend less on short-term debt (Figures 5 and 6). As a result, Japanese firms' bank borrowing, the main source of external funding, has declined to the level comparable to that in other advanced economies (Figure 7). In line with this trend, the liquidity ratio ${ }^{3}$, which showed a trend decline over the last two decades until the recent crisis on the back of large deleveraging, improved recently with the recovery of profitability in both sectors (Figure 8 ).
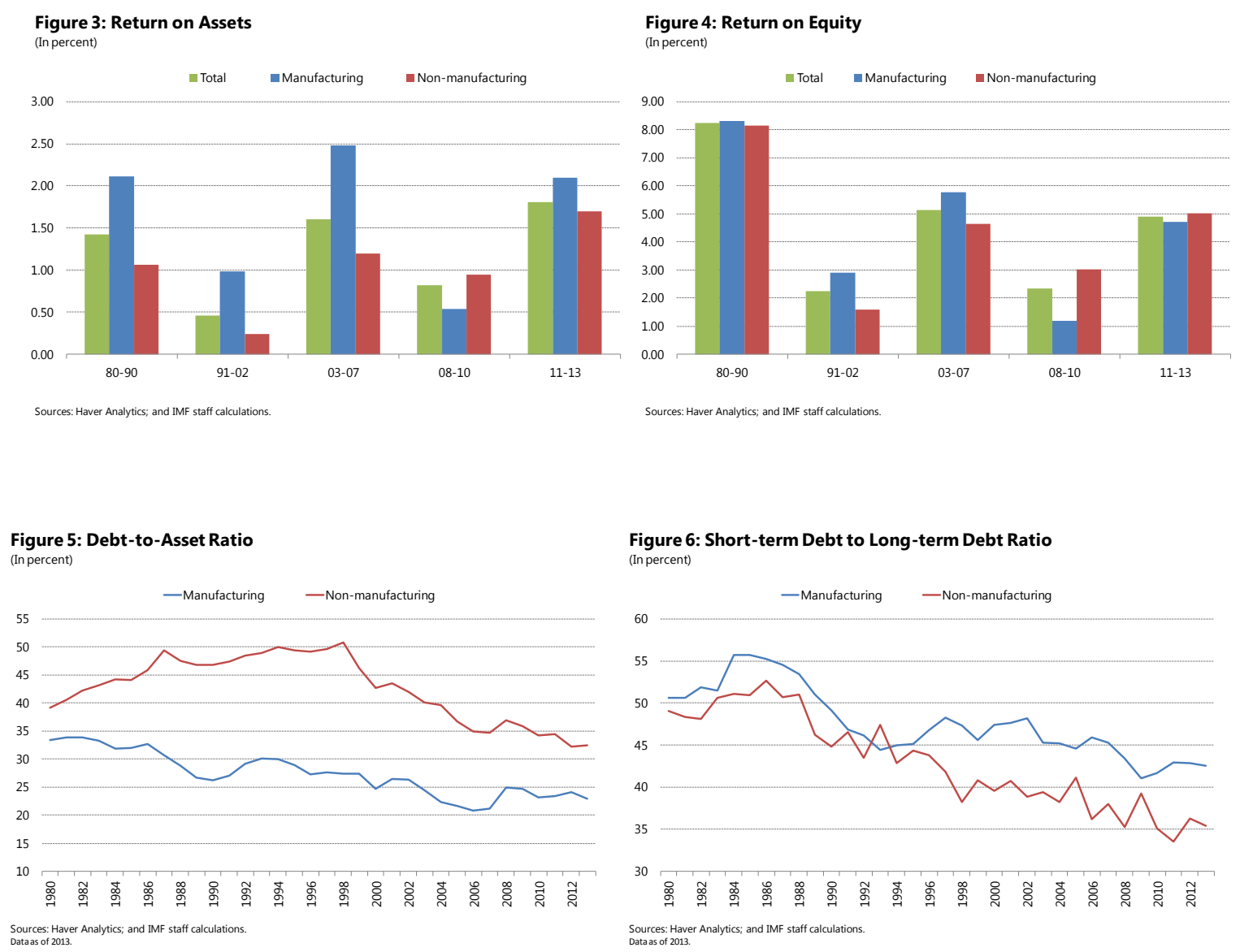

${ }^{3}$ A ratio of average of cash, deposits, and securities to total sales 


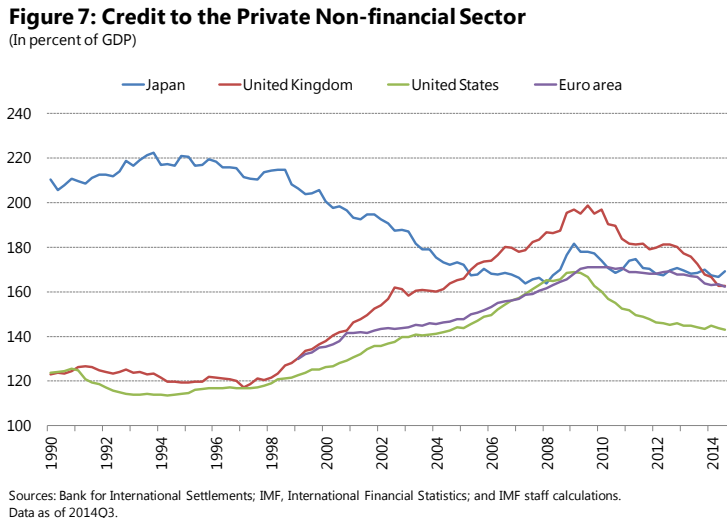

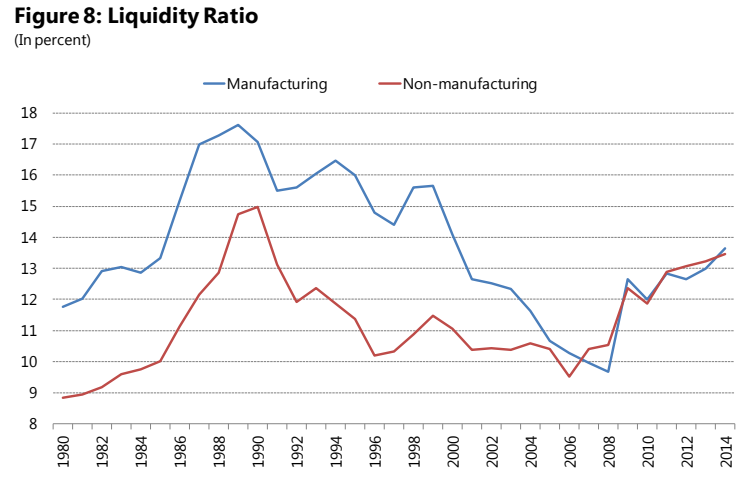
Sources: Haver Analytics; and IMF staff calculations.

We can observe similar patterns across different sizes of firms (Figures 9-12). ${ }^{4}$ Profitability has recovered to pre-crisis levels across all sizes of firms. Firms have currently a much lower debt payment burden thanks to the much lower level of leverage and lower interest rates. Accordingly, their liquidity conditions have improved in recent years. However, despite this notable improvement in financial conditions, the recovery in corporate investment remains subdued across all sizes of firms, in particular for large firms whose investment has been largely flat over the last few years.
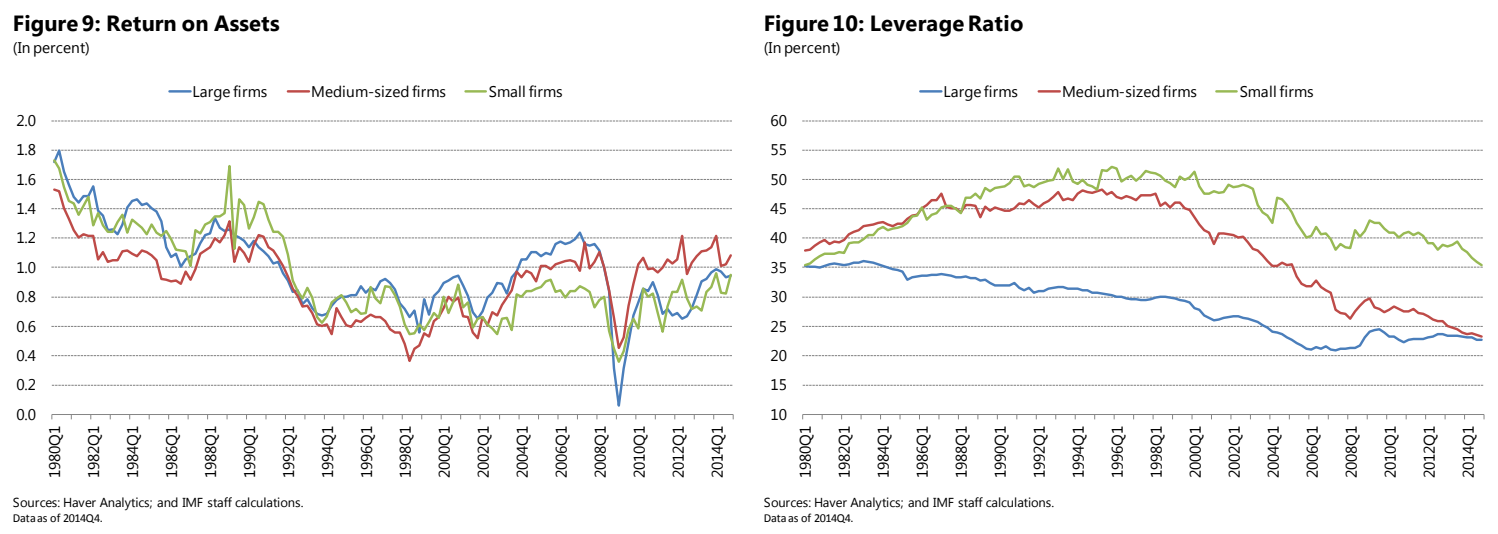

\footnotetext{
${ }^{4}$ Although the corporate survey is a quite comprehensive survey as noted above, this survey covers firms whose capital is more than 10 million yen. In this survey, large firms are those with capital more than 1 billion yen, medium firms are those with capital between 100 million and 1 billion yen, and small firms are those with capital between 10 million and 100 million yen.
} 

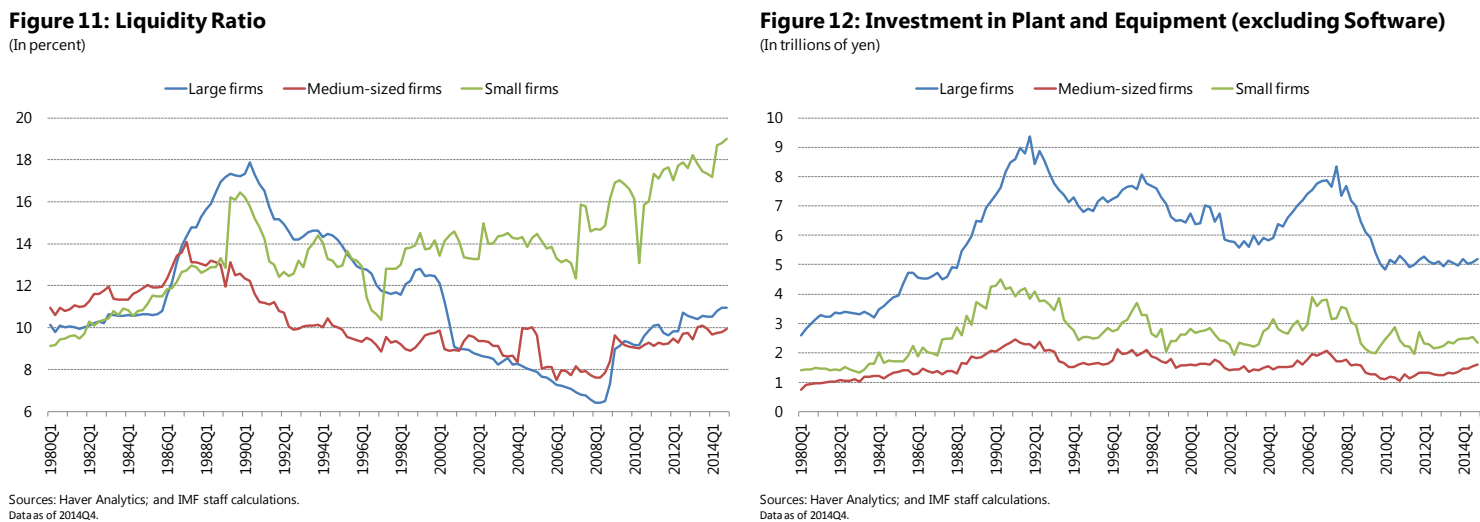
Sources: Haver Analytics; and IMF staff calculations

One notable feature of Japanese firms' behavior over the past decades is a trend increase in their offshore production. Over the last two decades, Japanese firms have expanded abroad to exploit labor cost differentials and rising demand in the host countries (IMF, 2011). Overseas investment grew at a rate of 7 percent in the mid-1990s and 12 percent before the global financial crisis. The pace has accelerated since, partly due to large yen appreciation during the crisis and uncertainty about energy supply after the 2011 earthquake (Figure 13). As a result, overseas investment now accounts for about 25 percent of total manufacturing investment, while domestic production capacity declined by about 4 percent since 2011 . In particular, the transportation sector has been the leading sector expanding abroad and now accounts for more than 60 percent of overseas investment (Figure 14). Accordingly, in 2014, exports by Japanese subsidiaries located overseas (to countries excluding Japan) exceeded exports from Japan by more than 40 percent (Figure 15). Botman and Kang (2014) note that Japan's deepening regional integration has largely been driven by the outsourcing of production by Japanese firms to neighboring countries. In addition, Kang (2015b) finds that Japanese firms' offshoring is the main driver behind the sluggish recovery of exports in recent years despite solid external demand growth and the large yen depreciation. In the following section, we investigate how the trend increase in production offshoring has affected overall investment behavior of Japanese firms.

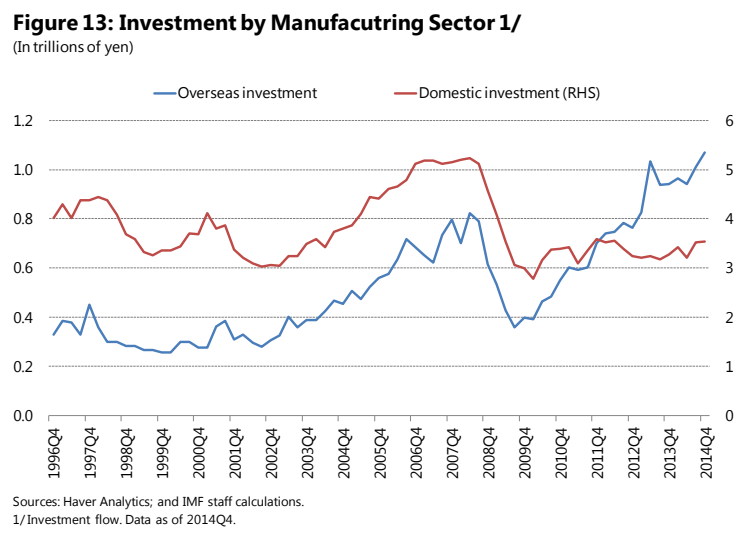

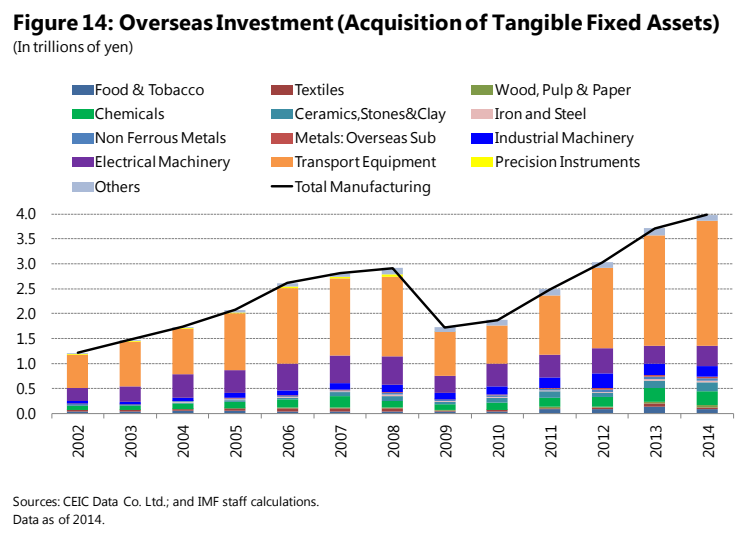




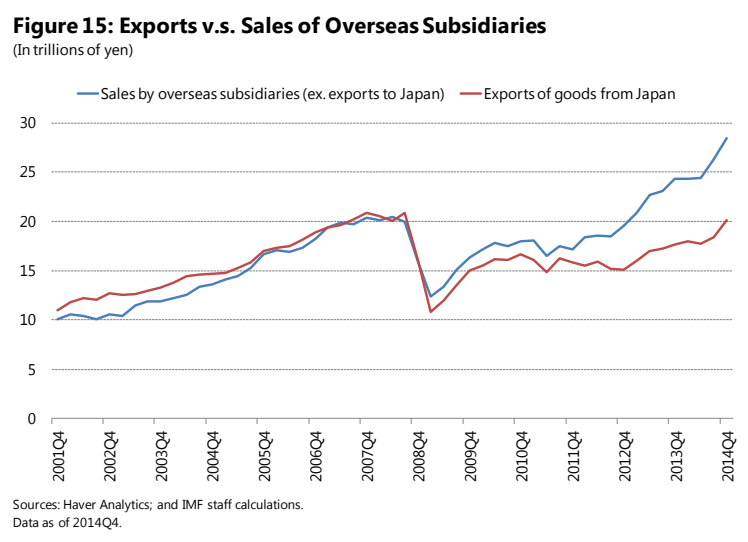

\section{Panel Regression With Firm-LeVel Data}

As discussed in the previous section, the corporate survey data provides a good overview of investment patterns across different types of firms and their financial conditions, but these stylized facts do not provide any causality between investment and its potential determinants. So, we now turn to firm-level data to better understand the links between investment and its determinants across different types of firms.

\section{Model and Data}

We estimate the standard neoclassical investment model, which relates investment to expectations of future profitability, cash flow, leverage as well as lagged investment. Since Hayashi's (1982) result that investment should depend only on Tobin's Q which captures the expectations of future profitability, the $\mathrm{Q}$ ratio has been at the center of the empirical investment literature. The potential role of financial frictions motivated the subsequent work on the cash-flow effect. As summarized in Hubbard (1998), many empirical studies have found that cash flow has a significant effect on investment, even if Tobin's Q is included as an explanatory variable. This finding has been interpreted by Fazzari, Hubbard, and Petersen (1988) and others as evidence of financing constraints facing firms. While lagged investment has not been used much in the literature mainly due to the lack of theoretical model to explain the lagged-investment effect, Eberly, Rebelo, and Vincent (2012) show analytically that the investment adjustment-cost model by Christiano, Eichenbaum, and Evans (2005), which is widely used as a standard theoretical background model in the DSGE literature, predicts the presence of a lagged-investment effect in addition to cash-flow and Q effects. ${ }^{5}$ They also empirically find the importance and robustness of the lagged-investment effect in firm-level data for U.S. manufacturing sector. Lastly, Guimarães-Filho, Piao, and Zhang

\footnotetext{
${ }^{5}$ See Appendix I for empirical analysis that confirms the importance of the lagged-investment effect in Japanese firms' investment.
} 
(2014) find that high leverage has a negative effect on investment in Asia using dynamic panel regression including Japan. ${ }^{6}$

So we include four variables in our firm-level investment regression: lagged investment, Q ratio, cash flow, and the leverage ratio as below:

$$
\frac{\mathrm{I}_{\mathrm{i}, \mathrm{t}}}{\mathrm{K}_{\mathrm{i}, \mathrm{t}-1}}=\mathrm{c}_{\mathrm{i}}+\beta_{1} \frac{\mathrm{I}_{\mathrm{i}, \mathrm{t}-1}}{\mathrm{~K}_{\mathrm{i}, \mathrm{t}-2}}+\beta_{2} \mathrm{Q}_{\mathrm{i}, \mathrm{t}}+\beta_{3} \frac{\mathrm{CF}_{\mathrm{i}, \mathrm{t}}}{\mathrm{K}_{\mathrm{i}, \mathrm{t}-1}}+\beta_{4} \mathrm{LEV}_{\mathrm{i}, \mathrm{t}}+\varepsilon_{\mathrm{i}, \mathrm{t}}
$$

where, $I$ is a capital expenditure, $K$ is a capital stock which is gross property, plant and equipment less accumulated reserves for depreciation, depletion and amortization. $C F$ is a cash flow which is proxied by post-income tax earnings before depreciation, and $L E V$ is a leverage ratio which is calculated by dividing total debt by common equity. $Q$ is the sum of market capitalization and total debt divided by total assets. ${ }^{7}$

Firm-level data is from Worldscope which covers more than 5,000 Japanese firms from FY1994 to FY2013 ${ }^{8}$, which accounts for about 55-60 percent of aggregate business investment over this period. ${ }^{9}$ In our empirical analysis below, we consider the 15 -year horizon from FY1999 to FY2013 as the sample size more than doubled from FY1999 onward. We exclude firms in the financial sector (and those not classified) following the convention in the literature and include only manufacturing and non-manufacturing firms in the estimation, which reduces the total number of firms to about 4,000. As the sizes of listed companies in this database are relatively larger than those of firms included in the corporate survey, most of firms in this database are classified as large firms according to the criterion in the corporate survey - capital of more than 1 billion yen - which we discussed in the previous section. So, for subsequent analysis in this section, we select only 486 mega firms with average capital over the sample period exceeding 100 billion yen and investigate their investment behavior compared to the others. Even though only 12 percent of firms are classified as large firms by this new criterion, they account for 85-90 percent of total investment in our sample (Figure 16). Similarly, less than 5 percent of firms in our sample

\footnotetext{
${ }^{6}$ Recent literature suggests that uncertainty is also an important factor in explaining firms' investment behavior. For example, building on an error correction model specified by Bloom, Bond, and Van Reenen (2007), Kang, Lee, and Rastii (2014) find that economic policy uncertainty in interaction with firm-level uncertainty depresses firms' investment decisions.

${ }^{7}$ Some literature takes the log of explanatory variables due to potential skewness in the data. However, we find that empirical results are similar, so report only those with level variables in this paper.

${ }^{8}$ Japanese firm's fiscal years begins in April and ends in March.

${ }^{9}$ Different from the national accounts or the corporate survey which include only domestic investment data, capital expenditure in this firm-level database is the sum of domestic and overseas investment of those firms which invest abroad as well. However, total investment by listed companies is strongly correlated with total aggregate domestic business investment (correlation of 0.8). Aslam et al. (2015) use this total investment series in firm-level database as a proxy for domestic investment.
} 
are operating overseas - proxied by those firms who have had fixed assets abroad over the last 5 years - , but they account for about 25 percent of total investment (Figure 17).
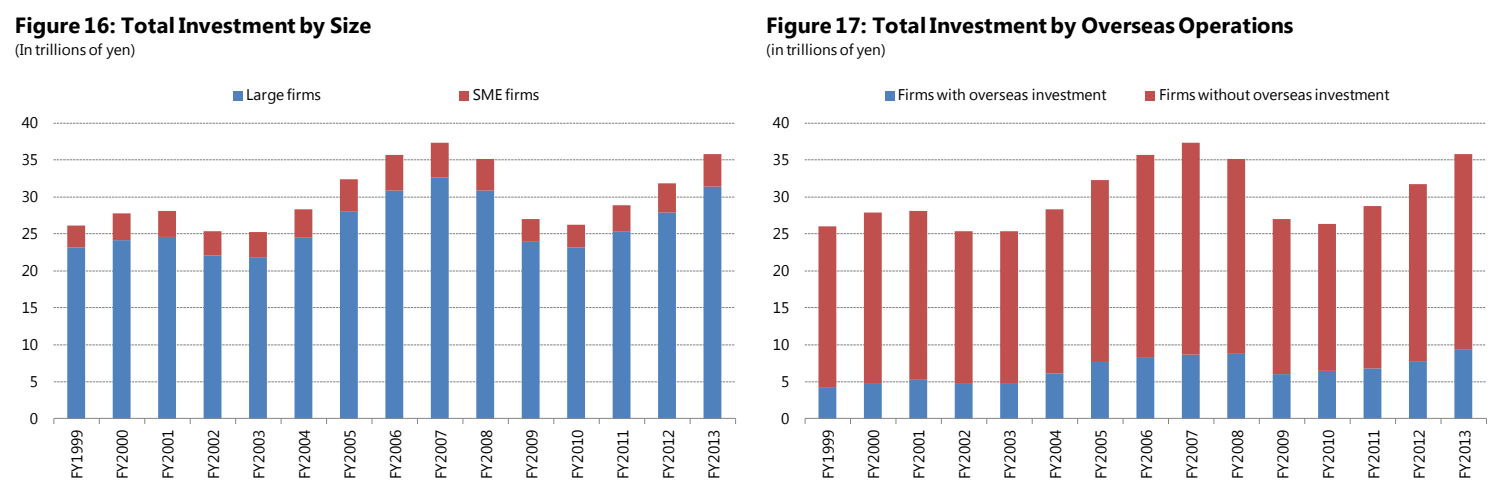

\section{Empirical results}

Figures 18-21 provide scatter plots of pooled time-series-cross-section data that are useful to visualize the relation between $I / K$ and the four variables of interest: $Q, C F / K, L E V$, and lagged $I / K$. As expected, we can observe that investment-to-capital ratio is positively correlated with Q ratio, cash flow, and its own lag and negatively correlated with leverage ratio.

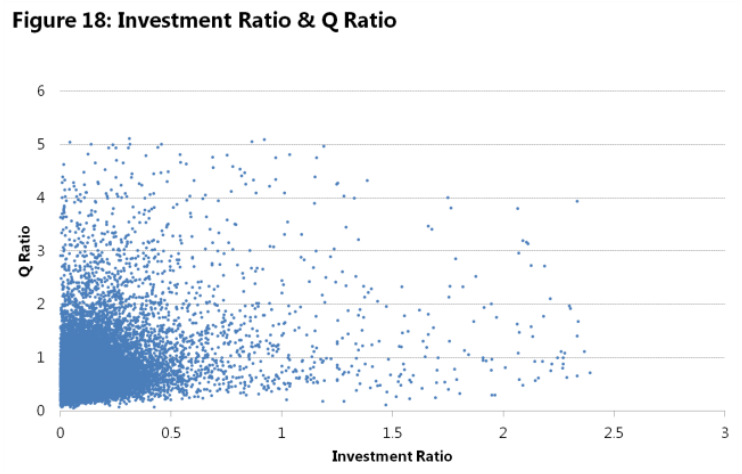

Sources: Thomson Reuters Worldscope: and IMF staff calculations

Figure 20: Investment Ratio \& Leverage Ratio

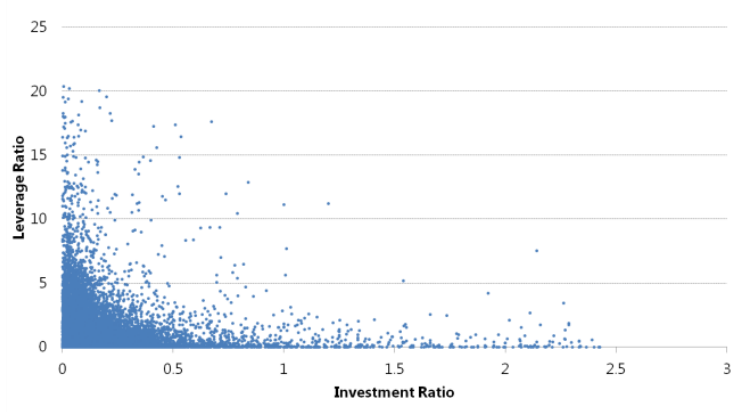

Sources: Thomson Reuters Worldscope and IMF staff calculations.

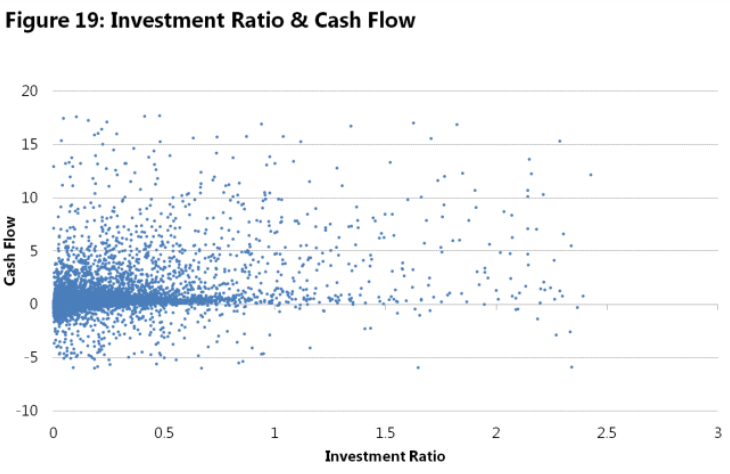

Sources: Thomson Reuters Worldscope: and IMF staff calculations

Figure 21: Investment Ratio \& Lagged Investment Ratio

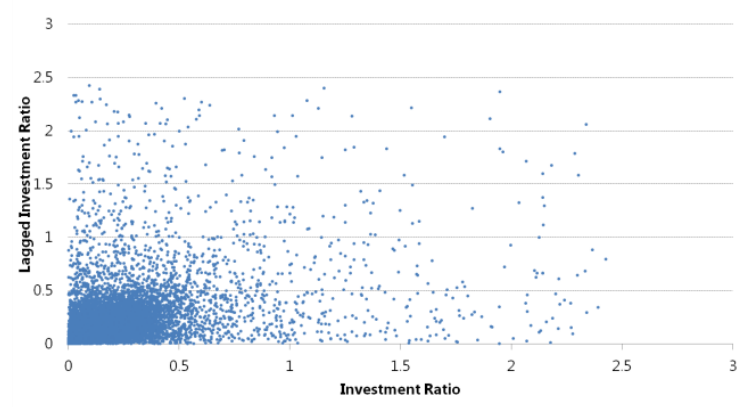

Sources: Thomson Reuters Wordscope and IMF staff calculations 
Table 1

\begin{tabular}{|c|c|c|c|c|c|c|}
\hline VARIABLES & $\begin{array}{c}\text { (1) } \\
\text { Full sample }\end{array}$ & $\begin{array}{c}\text { (2) } \\
\text { Manufacturing }\end{array}$ & $\begin{array}{c}\text { (3) } \\
\text { Non-manufacturing }\end{array}$ & $\begin{array}{c}\text { (4) } \\
\text { Full sample } \\
\text { Positive CF }\end{array}$ & $\begin{array}{c}(5) \\
\text { Manufacturing } \\
\text { Positive CF }\end{array}$ & $\begin{array}{c}(6) \\
\text { Non-manufacturing } \\
\text { Positive CF } \\
\end{array}$ \\
\hline L.Investment_ratio & $\begin{array}{l}0.192^{\star * *} \\
(12.878)\end{array}$ & $\begin{array}{l}0.237^{\star \star *} \\
(10.186)\end{array}$ & $\begin{array}{c}0.132^{\star \star *} \\
(7.033)\end{array}$ & $\begin{array}{l}0.177^{\star * \star} \\
(10.796)\end{array}$ & $\begin{array}{c}0.222^{* * *} \\
(8.371)\end{array}$ & $\begin{array}{c}0.111^{\star * *} \\
(5.262)\end{array}$ \\
\hline Q & $\begin{array}{c}0.066^{\star \star \star} \\
(9.415)\end{array}$ & $\begin{array}{c}0.065^{\star \star \star} \\
(8.147)\end{array}$ & $\begin{array}{c}0.076^{* \star *} \\
(6.366)\end{array}$ & $\begin{array}{c}0.064^{\star \star *} \\
(8.421)\end{array}$ & $\begin{array}{c}0.058^{\star \star *} \\
(7.041)\end{array}$ & $\begin{array}{c}0.068^{\star \star \star} \\
(5.182)\end{array}$ \\
\hline CF & $\begin{array}{c}0.049^{\star \star \star} \\
(7.236)\end{array}$ & $\begin{array}{c}0.036^{\star \star \star} \\
(3.658)\end{array}$ & $\begin{array}{c}0.046^{\star \star *} \\
(6.649)\end{array}$ & $\begin{array}{c}0.048^{* \star *} \\
(7.418)\end{array}$ & $\begin{array}{c}0.042^{* \star \star} \\
(3.851)\end{array}$ & $\begin{array}{c}0.043^{* \star *} \\
(6.283)\end{array}$ \\
\hline LEV & $\begin{array}{c}-0.006^{\star \star \star} \\
(-3.779)\end{array}$ & $\begin{array}{c}-0.009^{\star \star \star} \\
(-4.551)\end{array}$ & $\begin{array}{l}-0.005 \\
(-1.560)\end{array}$ & $\begin{array}{l}-0.004^{\star *} \\
(-2.473)\end{array}$ & $\begin{array}{c}-0.006^{\star \star \star} \\
(-3.155)\end{array}$ & $\begin{array}{l}-0.003 \\
(-1.111)\end{array}$ \\
\hline Constant & $\begin{array}{c}0.043^{\star \star \star} \\
(8.261)\end{array}$ & $\begin{array}{c}0.044^{\star \star \star} \\
(7.702)\end{array}$ & $\begin{array}{c}0.046^{\star \star \star} \\
(4.227)\end{array}$ & $\begin{array}{c}0.043^{\star \star \star} \\
(7.255)\end{array}$ & $\begin{array}{c}0.046^{\star \star \star} \\
(6.242)\end{array}$ & $\begin{array}{c}0.052^{\star \star \star} \\
(4.510)\end{array}$ \\
\hline Observations & 41,889 & 26,266 & 15,623 & 37,832 & 23,544 & 14,288 \\
\hline Number of ID & 3,933 & 2,260 & 1,673 & 3,892 & 2,240 & 1,652 \\
\hline R-squared & 0.258 & 0.269 & 0.234 & 0.289 & 0.295 & 0.269 \\
\hline
\end{tabular}

z-statistics in parentheses

${ }^{* \star *} p<0.01,{ }^{* *} p<0.05,{ }^{*} p<0.1$

Expectations of future profitability, cash flow, and leverage are all important factors for overall investment behavior of Japanese firms. The results from system-GMM estimation for all firms over the entire sample period are reported in column 1 of Table 1 . As expected, investment is positively associated with expectations of future profitability and cash flow while negatively associated with leverage. We can also see the lagged-investment effect from the statistically significant positive coefficient estimate on the lagged investment variable as in the case of the U.S. (Eberly, Rebelo, and Vincent, 2012). In columns 2 and 3, we can also observe that investment of manufacturing firms shows more persistence but is more constrained by leverage than that of non-manufacturing firms. It has been reported in the literature that firms with negative cash flows have driven investment down to its lowest possible level, so a few influential observation could reduce the estimated investment-cash flow sensitivity in overall sample (Allayannis and Mozumdar, 2001; McGuire, 2003). To investigate the robustness of the above findings, we run the same regression by excluding those firms with negative cash flows. As reported in columns 4 to 6 of Table 1, the above findings remain robust:expected profitability, liquidity, and leverage conditions are all important factors in determining the overall investment behavior of Japanese firms. In subsequent discussion, we focus only on those firms and observations with positive cash flows to avoid potential bias arising from a few influential observations with negative cash flows.

Why does corporate investment in Japan still remain subdued despite the strong rally in the stock market over the last few years? Our hypothesis is that investment behavior is different for large Japanese firms who account for a significant portion of total investment due to a trend increase in their overseas expansion. Columns 2 and 3 of Table 2 report the estimation results for those firms with overseas operation and the others who mainly operate in Japan, respectively. First, we can see that the coefficient estimate on Q ratio for firms with overseas operations is very small and not statistically significant, implying that these firms do not 
increase their investment even when expectations of future profitability improve. This is in sharp contrast to firms without overseas operations, whose investment is positively and statistically significantly associated with expected profitability. This different pattern is more pronounced in recent years. Columns 5 and 6 of Table 2 report the estimation results after the global financial crisis and the earthquake in 2011 during which Japanese firms' overseas expansion accelerated due to large yen appreciation with the onset of the global financial crisis and large uncertainty about energy supply. We can see that that the coefficient estimate on the $\mathrm{Q}$ ratio for these firms with overseas operation even turns negative though remaining statistically insignificant. Second, investment by firms with overseas operations is more sensitive to cash flow than that of firms operating domestically, and the sensitivity increases in recent years as the pace of overseas expansion is accelerating.

Table 2

\begin{tabular}{|c|c|c|c|c|c|c|}
\hline VARIABLES & $\begin{array}{c}\text { (1) } \\
\text { Full sample } \\
\text { Positive CF }\end{array}$ & $\begin{array}{c}\text { (2) } \\
\text { Full sample } \\
\text { Positive CF } \\
\text { Overseas(Y) }\end{array}$ & $\begin{array}{c}\text { (3) } \\
\text { Full sample } \\
\text { Positive CF } \\
\text { Overseas(N) }\end{array}$ & $\begin{array}{c}(4) \\
\text { Post crisis } \\
\text { Positive CF }\end{array}$ & $\begin{array}{c}(5) \\
\text { Post crisis } \\
\text { Positive CF } \\
\text { Overseas(Y) }\end{array}$ & $\begin{array}{c}(6) \\
\text { Post crisis } \\
\text { Positive CF } \\
\text { Overseas(N) }\end{array}$ \\
\hline L.Investment_ratio & $\begin{array}{l}0.177^{\star \star \star} \\
(10.796)\end{array}$ & $\begin{array}{c}0.424^{\star \star \star} \\
(5.534)\end{array}$ & $\begin{array}{l}0.169^{\star \star \star} \\
(10.356)\end{array}$ & $\begin{array}{c}0.118^{\star \star \star} \\
(4.916)\end{array}$ & $\begin{array}{l}0.652^{\star \star} \\
(2.566)\end{array}$ & $\begin{array}{c}0.110^{\star \star \star} \\
(4.627)\end{array}$ \\
\hline Q & $\begin{array}{c}0.064^{\star \star \star} \\
(8.421)\end{array}$ & $\begin{array}{c}0.013 \\
(0.556)\end{array}$ & $\begin{array}{c}0.065^{\star \star \star} \\
(8.022)\end{array}$ & $\begin{array}{l}0.028^{\star} \\
(1.700)\end{array}$ & $\begin{array}{c}-0.063 \\
(-0.387)\end{array}$ & $\begin{array}{l}0.034^{* *} \\
(1.977)\end{array}$ \\
\hline CF & $\begin{array}{c}0.048^{\star \star \star *} \\
(7.418)\end{array}$ & $\begin{array}{c}0.058^{\star \star \star} \\
(6.391)\end{array}$ & $\begin{array}{c}0.047^{\star \star \star} \\
(7.160)\end{array}$ & $\begin{array}{c}0.054^{* * *} \\
(6.100)\end{array}$ & $\begin{array}{l}0.089^{\star *} \\
(2.324)\end{array}$ & $\begin{array}{c}0.051^{\star * *} \\
(5.706)\end{array}$ \\
\hline LEV & $\begin{array}{l}-0.004^{\star *} \\
(-2.473)\end{array}$ & $\begin{array}{l}-0.003 \\
(-0.361)\end{array}$ & $\begin{array}{l}-0.004^{\star *} \\
(-2.478)\end{array}$ & $\begin{array}{c}-0.028^{\star \star \star} \\
(-4.655)\end{array}$ & $\begin{array}{c}0.001 \\
(0.186)\end{array}$ & $\begin{array}{c}-0.026^{\star \star \star} \\
(-4.418)\end{array}$ \\
\hline Constant & $\begin{array}{c}0.043^{\star \star \star \star} \\
(7.255)\end{array}$ & $\begin{array}{l}0.073^{\star \star} \\
(2.292)\end{array}$ & $\begin{array}{c}0.043^{\star \star \star *} \\
(7.046)\end{array}$ & $\begin{array}{c}0.084^{\star \star \star} \\
(7.045)\end{array}$ & $\begin{array}{c}0.086 \\
(0.876)\end{array}$ & $\begin{array}{c}0.078^{\star \star \star} \\
(6.431)\end{array}$ \\
\hline Observations & 37,832 & 2,299 & 35,533 & 10,802 & 651 & 10,151 \\
\hline Number of ID & 3,892 & 176 & 3,716 & 3,196 & 173 & 3,023 \\
\hline R-squared & 0.289 & 0.456 & 0.288 & 0.234 & 0.230 & 0.584 \\
\hline
\end{tabular}

z-statistics in parentheses

${ }^{\star * \star} p<0.01,{ }^{\star \star} p<0.05,{ }^{*} p<0.1$

What explains the limited impact of expectations of future profitability on investment of firms that are expanding abroad? It is beyond the scope of this paper to provide a theoretical model to explain this pattern, but one possible reason is a missing variable in the model specification. The standard model that we consider here assumes that expectations of future profitability are well captured by the $\mathrm{Q}$ ratio which is largely affected by stock price movement listed in Japanese stock exchanges. However, as only a fraction of profits generated from overseas operation are repatriated to Japan and a significant portion is reinvested abroad for further expansion of overseas operation, there is a possibility that the calculated Q ratio based on stock prices in Japanese stock exchanges does not fully capture the expected profitability for those firms operating overseas. As not all of firms are listed in overseas stock exchanges, we do not have a good proxy of the corresponding Q ratio which can better capture the expected profitability from overseas operation.. However, despite the issue of a potential missing variable, the R-squared of the regression for these firms is much larger than for other firms, confirming that cash flow is a more important factor determining investment behavior while domestic stock price movements are unimportant. 
The much larger coefficient estimate of the cash flow variable does not necessarily imply that these firms are financially more constrained that the others as usually interpreted in standard finance literature. As is well known, it is relatively larger firms that expand abroad while relatively small Japanese firms face more constraints on external financing. Abel and Eberly (2011) show analytically that cash flow can have a positive effect on investment even with perfect capital markets without financing constraints, in contrast to the common interpretation of the positive cash flow effect on investment as an evidence of financing constraints facing firms. So a bigger impact of cash flow on investment could simply indicate that firms need more cash or savings for investment. One possible explanation for higher sensitivity to the liquidity condition is that firms need to rely more on internal financing for overseas expansion as it is riskier by nature from financial intermediaries' perspective. Accordingly, external financing is more costly for overseas investment compared to the same size of domestic investment. Financial institutions would also require relatively healthier financial positions as a condition to lend for riskier overseas investment, including more liquidity in the balance sheet. Another explanation could be firms' increased reliance on intangible capital in their production technology. As intangible capital cannot be easily verified and liquidated, it cannot be pledged as collateral for external financing. So a trend increase in intangible assets has boosted firms' precautionary demand for cash. Falato, Kadyrzhanova, and Sim (2013) find empirical evidence that an increase in intangible capital generates an outsized increase in the demand for corporate cash for the U.S. firms.

Although we cannot test the hypothesis directly that production offshoring has changed firms' investment behavior due to the lack of firm-level data on overseas investment and Q ratio capturing expected profits from overseas operation, the above findings provide some evidence that firms with overseas operation respond less to Tobin's Q but more to cash flow. To further investigate whether a trend increase in production offshoring has been an important factor behind this investment behavior, we also estimate the above investment model across different sizes of firms and different sectors as it is relatively larger firms that expand their business abroad and about two-thirds of overseas investment has been made in the transportation sector.

Consistent with our hypothesis, investment by mega firms and by firms in the transportation sector depends more on cash flow and less on Tobin's Q. Columns 1 and 2 of Table 3 report the estimation results for mega firms and relatively smaller firms, respectively, over the full sample period. Investment by mega firms is less positively associated with expectations of future profitability, with the coefficient on the $\mathrm{Q}$ ratio being less than half of that for smaller firms. In contrast, cash flow is a more important factor behind mega firms' investment, with the corresponding coefficient being more than twice as large as that for smaller firms. We can also observe that these patterns become more apparent in recent years (columns 3 and 4) in line with the acceleration of overseas investment by Japanese firms. The coefficient estimate on the $\mathrm{Q}$ ratio becomes even negative for mega firms and that on cash flow becomes larger. Similarly, firms in the transportation sector rely more on cash flow for their investment and less on Tobin's Q, compared to firms in the other sectors (Columns 5 to 8 ). 
Table 3

\begin{tabular}{|c|c|c|c|c|c|c|c|c|}
\hline VARIABLES & $\begin{array}{c}\text { (1) } \\
\text { Full sample } \\
\text { Positive CF } \\
\text { Large }\end{array}$ & $\begin{array}{c}(2) \\
\text { Full sample } \\
\text { Positive CF } \\
\text { SME }\end{array}$ & $\begin{array}{c}\text { (3) } \\
\text { Post crisis } \\
\text { Positive CF } \\
\text { Large }\end{array}$ & $\begin{array}{c}(4) \\
\text { Post crisis } \\
\text { Positive CF } \\
\text { SME }\end{array}$ & $\begin{array}{c}\text { (5) } \\
\text { Full sample } \\
\text { Positive CF } \\
\text { Transpotation }\end{array}$ & $\begin{array}{c}\text { (6) } \\
\text { Full sample } \\
\text { Positive CF } \\
\text { Other sectors }\end{array}$ & $\begin{array}{c}(7) \\
\text { Post crisis } \\
\text { Positive CF } \\
\text { Transpotation }\end{array}$ & $\begin{array}{c}(8) \\
\text { Post crisis } \\
\text { Positive CF } \\
\text { Other sectors }\end{array}$ \\
\hline L.Investment_ratio & $\begin{array}{c}0.153^{\star \star *} \\
(4.076)\end{array}$ & $\begin{array}{c}0.168^{\star \star *} \\
(9.881)\end{array}$ & $\begin{array}{c}0.092 \\
(0.763)\end{array}$ & $\begin{array}{c}0.118^{\star * *} \\
(4.608)\end{array}$ & $\begin{array}{c}0.219^{\star \star *} \\
(4.804)\end{array}$ & $\begin{array}{c}0.165^{\star \star \star} \\
(9.390)\end{array}$ & $\begin{array}{c}0.342^{\star \star *} \\
(7.617)\end{array}$ & $\begin{array}{c}0.102^{\star \star *} \\
(4.055)\end{array}$ \\
\hline Q & $\begin{array}{l}0.030^{* *} \\
(1.972)\end{array}$ & $\begin{array}{c}0.070^{\star \star \star \star} \\
(8.128)\end{array}$ & $\begin{array}{l}-0.042^{\star} \\
(-1.751)\end{array}$ & $\begin{array}{l}0.039^{\star *} \\
(2.146)\end{array}$ & $\begin{array}{c}0.055^{\star \star \star} \\
(3.005)\end{array}$ & $\begin{array}{l}0.062^{\star \star \star *} \\
(7.679)\end{array}$ & $\begin{array}{l}-0.053^{*} \\
(-1.792)\end{array}$ & $\begin{array}{l}0.035^{\star \star} \\
(1.995)\end{array}$ \\
\hline CF & $\begin{array}{c}0.094^{\star \star *} \\
(2.859)\end{array}$ & $\begin{array}{c}0.044^{\star \star *} \\
(6.772)\end{array}$ & $\begin{array}{c}0.115^{\star \star \star} \\
(3.299)\end{array}$ & $\begin{array}{c}0.046^{\star \star \star} \\
(5.446)\end{array}$ & $\begin{array}{c}0.102^{\star \star \star} \\
(2.694)\end{array}$ & $\begin{array}{c}0.046^{\star \star \star} \\
(6.963)\end{array}$ & $\begin{array}{c}0.132^{\star \star \star *} \\
(2.873)\end{array}$ & $\begin{array}{c}0.050^{\star \star \star} \\
(5.319)\end{array}$ \\
\hline LEV & $\begin{array}{c}-0.003 \\
(-1.118)\end{array}$ & $\begin{array}{c}-0.005^{\star \star *} \\
(-2.745)\end{array}$ & $\begin{array}{l}-0.011^{\star *} \\
(-2.166)\end{array}$ & $\begin{array}{c}-0.028^{\star \star *} \\
(-3.786)\end{array}$ & $\begin{array}{c}-0.004 \\
(-1.247)\end{array}$ & $\begin{array}{l}-0.004^{\star *} \\
(-2.224)\end{array}$ & $\begin{array}{c}-0.001 \\
(-0.128)\end{array}$ & $\begin{array}{c}-0.023^{\star * *} \\
(-3.599)\end{array}$ \\
\hline Constant & $\begin{array}{c}0.076^{\star \star \star} \\
(4.960)\end{array}$ & $\begin{array}{c}0.042^{* * *} \\
(6.547)\end{array}$ & $\begin{array}{c}0.131^{\star \star \star} \\
(5.646)\end{array}$ & $\begin{array}{c}0.077^{\star \star \star} \\
(5.957)\end{array}$ & $\begin{array}{c}0.056^{\star \star \star *} \\
(4.453)\end{array}$ & $\begin{array}{c}0.044^{\star \star \star *} \\
(7.024)\end{array}$ & $\begin{array}{l}0.082^{\star \star \star *} \\
(5.102)\end{array}$ & $\begin{array}{c}0.077^{\star * *} \\
(5.911)\end{array}$ \\
\hline Observations & 5,971 & 31,861 & 1,605 & 9,197 & 5,527 & 32,305 & 1,524 & 9,278 \\
\hline Number of ID & 484 & 3,408 & 441 & 2,755 & 486 & 3,406 & 434 & 2,762 \\
\hline R-squared & 0.328 & 0.288 & 0.220 & 0.236 & 0.271 & 0.294 & 0.258 & 0.241 \\
\hline
\end{tabular}

z-statistics in parentheses

${ }^{\star \star \star} p<0.01,{ }^{\star \star} p<0.05,{ }^{*} p<0.1$

\section{CONCLUSION}

Despite the significant improvement in financial conditions, including firms' profitability, since the launch of Abenomics, the recovery of corporate investment has remained subdued. While slow progress in structural reforms, which has not yet substantially boosted confidence and improved the demand outlook, may be part to blame, this paper finds that the trend increase in production offshoring has played an important role. For large companies who have expanded abroad to explore rising demand overseas, especially in the transportation sector, expectations of future profitability measured by Tobin's Q based on stock prices in Japanese stock exchanges is a less important factor for overall investment decision. Rather their investment is more positively associated with their cash flow position, but not because they are liquidity constrained but rather because they have to count more on internal financing for overseas expansion. These findings imply that structural impediments stemming from a trend increase in production offshoring, in addition to headwinds from population aging, could be larger than expected drag on domestic investment although Abenomics substantially improved financial conditions, including through the sharp yen depreciation. So more ambitious structural reforms would be needed to provide a robust long-term outlook and underpin near-term demand. 


\section{REFERENCES}

Abel, A. B. and J. C. Eberly, 2011, "How Q and cash flow affect investment without frictions: an analytic explanation," Review of Economic Studies 78 (4): 1179-1200.

Allayannis, G., and A. Mozumdar, 2001, "The investment-cash flow sensitivity puzzle: can negative cash flow observations explain it?" Virginia Tech Working Paper 98-5.

Aslam A., S. Beidas-Strom, D. Leigh, S. G. Park, and H. Tong, 2015 "Private investment: what's the holdup?," Chapter 3 in World Economic Outlook (April) (Washington: International Monetary Fund).

Botman, D. and J. S. Kang, 2015, "Japan's Role in the Global Economy and Spillover Effects of Abenomics," Chapter 10 in Can Abenomics Succeed? Overcoming the Legacy of the Lost Decades, D. Botman, S. Danninger, and J Schiff and eds. (Washington: International Monetary Fund).

Bloom, N., S. Bond, and J. Van Reenen, 2007, "Uncertainty and Investment Dynamics" Review of Economic Studies 74, 391-415.

Christiano, L., Eichenbaum, M., Evans, C., 2005, "Nominal rigidities and the dynamic effects of a shock to monetary policy," Journal of Political Economy 113: 1-45.

Eberly J., S. Rebelo, and N. Vincent, 2012, "What explains the lagged-investment effect?" Journal of Monetary Economics 59: 370-380.

Falato, A., D. Kadyrzhanova, and J. W. Sim, 2013, "Rising intangible capital, shrinking debt capacity, and the US corporate savings glut," Federal Reserve Board Finance and Economics Discussion Series 2013-67.

Fazzari, S., G. Hubbard, and B. Petersen, 1988, "Financing constraints and corporate investment," Brookings Papers on Economic Activity 141-195.

Hayashi, F., 1982, "Tobin's marginal Q and average Q: a neoclassical interpretation," Econometrica 50: 215-224.

Hubbard, R.G., 1998, “Capital-market imperfections and investment," Journal of Economic Literature 36:193-225.

International Monetary Fund, 2011, “Japan: Spillover Report,” IMF Country Report No. 11/183.

Guimarães-Filho R., S. Piao, and L. Zhang, 2014, "Corporate leverage in Asia: a fault line?" Chapter 2 in Regional Economic Outlook: Asia and Pacific (Washington: International Monetary Fund). 
Kang, J. S., 2014, "How to raise private non-residential investment in Japan?," IMF WP 14/141 (Washington: International Monetary Fund).

Kang, J. S., 2015a, "Stimulating Private Investment and Innovation," Chapter 9 in Can Abenomics Succeed? Overcoming the Legacy of the Lost Decades, D. Botman, S. Danninger, and J Schiff and eds. (Washington: International Monetary Fund).

Kang, J. S., 2015b, “What explains Japan's export sluggishness?” Box 1 in "Japan: Staff Report for the 2015 Article IV Consultation, forthcoming IMF Country Report.

Kang, W., K. Lee, and R. A. Ratti, 2014, “Economic policy uncertainty and firm-level investment," Journal of Macroeconomics 39: 42-53.

McGuire, P. M, 2003, "Bank ties and bond market access: evidence on investment-cash flow sensitivity in Japan,” BIS Working Papers No. 151 (Bank for International Settlements).

Syed, M. and J. Lee, 2010, “Japan's Quest for Growth: Exploring the Role of Capital and Innovation," IMF Working Paper, WP/10/294 (Washington: International Monetary Fund). 


\section{APPEndix. Lagged InVestment}

To empirically confirm that lagged investment is a better predictor than the other variables for investment, we now describe results from regressing $\mathrm{I} / \mathrm{K}$ on different combinations of four variables: $\mathrm{Q}, \mathrm{CF} / \mathrm{K}, \mathrm{LEV}$, and lagged I/K. In Panel A of Table A1, the results from pooled time-series-cross-section regressions are reported. We can see from columns 2 to 4 that regressing $\mathrm{I} / \mathrm{K}$ on either of $\mathrm{Q}, \mathrm{CF} / \mathrm{K}$, or $\mathrm{LEV}$ generates an $\mathrm{R}^{2}$ of less than 0.15 . When all of these variables are included in the regression (column 5), the goodness-of-fit rises slightly to 0.17 . A higher $R^{2}(0.22)$ is obtained when we use lagged $I / K$ as the sole explanatory variable (column 1). When all four regressors are present, the coefficient on lagged $\mathrm{I} / \mathrm{K}$ remains large (0.35) and very highly significant, while the coefficients on $\mathrm{Q}, \mathrm{CF} / \mathrm{K}$, and LEV are highly significant as well but smaller compared to individual regression.

To investigate the robustness of the lagged-investment effect, we run panel versions of these regressions with firm fixed effects. The results, reported in Panel B of Table A1, also show the importance of lagged-investment effect, with the explanatory power is close to that of $\mathrm{Q}$, $\mathrm{CF} / \mathrm{K}$, and LEV together $\left(\mathrm{R}^{2}\right.$ of 0.44 versus 0.46$)$. When all four variables are included as regressors, the goodness-of-fit rises marginally to 0.48 and the coefficient on all variables remain highly significant and close to those in individual regression.

Since lagged investment is by definition correlated with the panel-level effects, we re-run the panel regressions using system GMM estimator. The results are reported in Panel C of Table A1. The lagged-investment effect continues to be highly significant even when year dummies are included (column 3) and is present in both subsamples (FY1999-FY2007 and FY2010FY2013 in columns 4 and 5). The coefficient on lagged I/K remains highly significant when we include $\mathrm{Q}, \mathrm{CF} / \mathrm{K}$, and LEV (column 2). Based on above findings, we include laggedinvestment but no time dummies in regression analysis and report only system GMM estimation results. 
Table A1

\begin{tabular}{|c|c|c|c|c|c|c|}
\hline \multicolumn{7}{|c|}{ Panel A: pooled OLS } \\
\hline VARIABLES & $(1)$ & (2) & (3) & $(4)$ & $(5)$ & $(6)$ \\
\hline L.Investment_ratio & $\begin{array}{l}0.444^{\star \star \star} \\
(41.862)\end{array}$ & & & & & $\begin{array}{l}0.344^{\star * *} \\
(27.633)\end{array}$ \\
\hline Q & & $\begin{array}{l}0.118^{\star \star \star} \\
(29.856)\end{array}$ & & & $\begin{array}{l}0.082^{* \star *} \\
(20.599)\end{array}$ & $\begin{array}{l}0.049^{\star \star \star} \\
(15.534)\end{array}$ \\
\hline CF & & & $\begin{array}{l}0.055^{\star \star \star} \\
(23.875)\end{array}$ & & $\begin{array}{l}0.042^{\star \star \star} \\
(16.443)\end{array}$ & $\begin{array}{l}0.032^{\star \star \star} \\
(14.110)\end{array}$ \\
\hline LEV & & & & $\begin{array}{c}-0.010^{\star \star \star} \\
(-9.505)\end{array}$ & $\begin{array}{c}-0.005^{\star \star \star} \\
(-6.025)\end{array}$ & $\begin{array}{c}-0.003^{\star \star \star} \\
(-5.651)\end{array}$ \\
\hline Constant & $\begin{array}{l}0.087^{\star \star \star} \\
(45.329)\end{array}$ & $\begin{array}{l}0.063^{\star \star \star} \\
(22.090)\end{array}$ & $\begin{array}{l}0.133^{\star \star *} \\
(74.508)\end{array}$ & $\begin{array}{l}0.175^{\star \star \star} \\
(68.173)\end{array}$ & $\begin{array}{l}0.075^{\star \star \star} \\
(26.565)\end{array}$ & $\begin{array}{l}0.048^{\star \star *} \\
(20.658)\end{array}$ \\
\hline $\begin{array}{l}\text { Observations } \\
\text { R-squared }\end{array}$ & $\begin{array}{c}45,176 \\
0.220\end{array}$ & $\begin{array}{c}46,318 \\
0.098\end{array}$ & $\begin{array}{c}46,121 \\
0.147\end{array}$ & $\begin{array}{c}47,142 \\
0.005\end{array}$ & $\begin{array}{c}43,913 \\
0.167\end{array}$ & $\begin{array}{c}41,889 \\
0.290\end{array}$ \\
\hline \multicolumn{7}{|c|}{ Panel B: panel regressions with firm fixed effects } \\
\hline VARIABLES & $(1)$ & $(2)$ & (3) & (4) & (5) & (6) \\
\hline L.Investment_ratio & $\begin{array}{c}0.080^{\star * \star} \\
(6.881)\end{array}$ & & & & & $\begin{array}{c}0.087^{\star \star \star} \\
(6.971)\end{array}$ \\
\hline Q & & $\begin{array}{l}0.060^{\star \star *} \\
(13.845)\end{array}$ & & & $\begin{array}{l}0.047^{\star * *} \\
(10.010)\end{array}$ & $\begin{array}{c}0.042^{\star \star \star} \\
(9.664)\end{array}$ \\
\hline CF & & & $\begin{array}{l}0.041^{\star \star \star} \\
(15.535)\end{array}$ & & $\begin{array}{l}0.036^{\star \star \star} \\
(11.460)\end{array}$ & $\begin{array}{l}0.037^{\star \star \star} \\
(10.894)\end{array}$ \\
\hline LEV & & & & $\begin{array}{c}-0.009^{\star \star \star} \\
(-6.609)\end{array}$ & $\begin{array}{c}-0.005^{\star \star \star} \\
(-3.811)\end{array}$ & $\begin{array}{c}-0.004^{\star \star \star} \\
(-3.512)\end{array}$ \\
\hline Constant & $\begin{array}{l}0.147^{\star \star \star} \\
(76.436)\end{array}$ & $\begin{array}{l}0.108^{\star \star \star} \\
(31.392)\end{array}$ & $\begin{array}{c}0.140^{\star \star \star} \\
(111.865)\end{array}$ & $\begin{array}{c}0.174^{\star \star \star} \\
(144.777)\end{array}$ & $\begin{array}{l}0.105^{\star \star \star} \\
(28.594)\end{array}$ & $\begin{array}{l}0.092^{\star \star \star} \\
(22.813)\end{array}$ \\
\hline Observations & 45,176 & 46,318 & 46,121 & 47,142 & 43,913 & 41,889 \\
\hline R-squared & 0.443 & 0.434 & 0.463 & 0.439 & 0.464 & 0.477 \\
\hline Number of ID & 4,009 & 3,997 & 3,999 & 4,021 & 3,964 & 3,933 \\
\hline \multicolumn{7}{|c|}{ Panel C: system GMM regressions with firm fixed effects } \\
\hline VARIABLES & $(1)$ & $(2)$ & (3) & $(4)$ & $(5)$ & \\
\hline L.Investment_ratio & $\begin{array}{l}0.207^{\star \star *} \\
(12.505)\end{array}$ & $\begin{array}{l}0.192^{\star * \star} \\
(12.878)\end{array}$ & $\begin{array}{l}0.176^{\star * *} \\
(12.323)\end{array}$ & $\begin{array}{c}0.196^{* \star *} \\
(9.801)\end{array}$ & $\begin{array}{c}0.139^{\star * \star} \\
(5.854)\end{array}$ & \\
\hline Q & & $\begin{array}{c}0.066^{\star \star *} \\
(9.415)\end{array}$ & $\begin{array}{c}0.072^{\star \star \star} \\
(7.548)\end{array}$ & $\begin{array}{c}0.053^{* * *} \\
(6.923)\end{array}$ & $\begin{array}{c}0.053^{\star \star *} \\
(3.314)\end{array}$ & \\
\hline $\mathrm{CF}$ & & $\begin{array}{c}0.049^{\star \star \star} \\
(7.236)\end{array}$ & $\begin{array}{c}0.051^{\star * \star} \\
(7.638)\end{array}$ & $\begin{array}{c}0.067^{\star \star \star} \\
(5.848)\end{array}$ & $\begin{array}{c}0.049^{\star * \star} \\
(5.398)\end{array}$ & \\
\hline LEV & & $\begin{array}{c}-0.006^{\star \star \star} \\
(-3.779)\end{array}$ & $\begin{array}{c}-0.006^{\star * \star} \\
(-3.629)\end{array}$ & $\begin{array}{c}-0.004^{\star \star \star} \\
(-2.931)\end{array}$ & $\begin{array}{c}-0.031^{\star \star \star} \\
(-4.281)\end{array}$ & \\
\hline Constant & $\begin{array}{l}0.114^{\star \star \star} \\
(37.096)\end{array}$ & $\begin{array}{c}0.043^{\star \star \star} \\
(8.261)\end{array}$ & $\begin{array}{c}0.275 \\
(0.489)\end{array}$ & $\begin{array}{c}0.053^{\star \star \star} \\
(8.186)\end{array}$ & $\begin{array}{c}0.071^{\star \star \star} \\
(5.658)\end{array}$ & \\
\hline Observations & 45,176 & 41,889 & 41,889 & 24,309 & 11,498 & \\
\hline Number of ID & 4,009 & 3,933 & 3,933 & 3,650 & 3,261 & \\
\hline Sample & FY1999-FY2013 & FY1999-FY2013 & FY1999-FY2013 & FY1999-FY2007 & FY2010-FY2013 & \\
\hline Time dummies & No & No & Yes & No & No & \\
\hline
\end{tabular}

